\title{
THE ROUNDTABLE TALKS OF 1989: PARTICIPANTS, POLITICAL VISIONS, AND HISTORICAL REFERENCES
}

\author{
ANDRÁS BOZÓKI \\ Central European University, Budapest, Hungary, \\ Department of Government, Smith College, Northampton, MA, \\ USA
}

\section{Introductory Remarks}

In East Central Europe the Poles began the first transition to democracy, and therefore the Polish opposition had to behave in a most cautious manner. Originally the Polish roundtable talks were not so much about paving the way for a full democracy, rather they were meant to produce an agreement. This agreement was designed first to legalize Solidarity and second to set up semi-democratic and partially fixed elections. ${ }^{1}$ As a result the June 1989 elections in Poland could not be evaluated as fully democratic ones.

In historical perspective, on the other hand, one can safely say that the Polish negotiations had already started in August 1980. Polish dissidents became the pioneers in inventing negotiations with the communists in the region. ${ }^{2}$ The selflimiting revolution of Solidarity in 1980-1981 set a pattern of behavior for other opposition groups in East Central Europe. For Poland 1989 meant simply the last chapter of a long historical process, which had been a decade-long transition first from communism to an authoritarian military regime and then to democracy. Viewed from a narrower perspective, between February and April 1989 the Poles closed an era of military dictatorship. The first task was to restore legality and the granting of legalization to Solidarity. The governing bloc, not the opposition, had initiated these steps after the failure of the 1988 referendum. By late 1988 even the communists had to realize that there was no other option for them.

While the Polish and the Hungarian roundtable talks represented efforts at extrications from dictatorships, the German and Czechoslovakian roundtable talks only came after the actual revolutionary changes had occurred. In Germany and Czechoslovakia the discussions were about the establishment of the institutional structures for the new regimes, because the extrications from the dictatorships had already been accomplished. Poland was the first to undertake the transition but ended up with semi-free elections. The intention of the Hungarian negotiators, who started after the Poles, was to start down the Polish path but to achieve more than the Poles had. 
In Hungary the roundtable talks actually mattered in both senses. The negotiations were meant to be the extrication from the old regime and also the creation of an institutional order for a democratic government. ${ }^{3}$

There were overt references to Poland by the Hungarian negotiators. ${ }^{4}$ Many people openly held the view that the Polish opposition could agree with the communists on a semi-free election as a compromise because it was much stronger than the Hungarian opposition. In effect the Poles could afford to accept substantial compromises because they were strong enough to mobilize masses of people on the streets and could thereby hope to change the results of the round table talks later. ${ }^{5}$ According to this argument, the Polish negotiators could accept a compromise without damaging their political credibility.

The Hungarian National Roundtable negotiations occurred after the Polish elections. Therefore in many respects the task of the Hungarians proved to be easier than that of the path-breaking Poles. The negotiations took place between the oppression of the student demonstrations at Tienanmen Square in China in June 1989 and the formation to the first non-communist Polish government after four decades in September 1989. Between June and September of that year, between the Polish elections in early June and the beginning of Leipzig's Monday demonstrations in mid-September, only Hungary was on the road to democratization. The Hungarian negotiations occurred with the participation of three sides: the MSZMP [the communist party], the Opposition Roundtable, and the so-called "Third Side" (which included the satellite organizations of the communist party and had been invited to join the talks by the MSZMP). Despite some suggestions to the contrary from reformist circles the Opposition Roundtable refused to negotiate with the incumbent cabinet and insisted on the idea of bilateral talks only with the communist party. The opposition wanted to draw a symbolic line between "us" and "them." Had the change of regimes already taken place, the opposition would then have negotiated the policy issues with the cabinet. But in the early summer of 1989 that was not yet the case. The Hungarian Constitution still declared that "the leading force of our society is the Hungarian Socialist Worker's Party."

In such a situation the opposition had to negotiate with the real holder of power: the communist party. The cabinet was not against the transition; it was the communist party that symbolized the old regime and stood to be the obstacle of change. As a compromise, however, the Opposition Roundtable accepted the representatives of some of the satellite organizations of the Party as participants. Therefore, the negotiations became trilateral discussions.

In formal terms the negotiations were designed to occur on three levels (plenary sessions, middle-level sessions and working sessions) between three negotiating parties, and included the participation of sixteen organizations represented by altogether 573 individuals. (For the structure of the National Roundtable talks, 
see Appendix 1.) During these three summer months of 1989 Hungary captured the attention of the international press. During that summer the democratization process in Hungary was not yet completed; it was just in the making. Although the negotiators were divided in their tactical and strategic considerations, and some of them were "ultra-moderates," they did not have to compromise on the outcome of the talks. Their compromises concerned only the modes of the transition.

Among the members of the Opposition Roundtable some political parties, the ultra-moderates, were ready to offer strategic concessions. Nevertheless, those parties that differed primarily in their tactical rather than their strategic considerations kept the ultra-moderates in the background. The moderates controlled the ultra-moderates by engaging in tactical compromises, while the radicals played within the rules of the game by following self-limiting political behavior and urging the moderates to limit their tactical concessions. This delicate balance was characteristic of the internally fragile Opposition Roundtable, which despite its internal fragility was able to stay together until the agreement of September 1989. (For the internal divisions of the Opposition Roundtable and the National Roundtable talks see Appendix 2.)

Transitions are usually pictured in the literature as elite games. ${ }^{6}$ True, it is hard to form a democracy without the existence of an elite/counter-elite, which are both willing to commit themselves to negotiating frames for a democratic process. Since Schumpeter it has been commonly held that elites and democracy are not incompatible concepts, both are important. ${ }^{7}$ Still, I would not subscribe completely to the idea that the Hungarian transition was only a game of the elite groups. It was an elite-driven process, but it was not fully an elitist exchange. There was interplay between the masses and the elite; and the elite and non-elite linkages were observable on many different occasions. ${ }^{8}$ On March 15, 1989, for instance, there was a huge mass demonstration in Budapest, where speakers openly called for a unification of the opposition because they recognized the danger that the communist party might divide the opposition by negotiating with its representatives one by one. ${ }^{9}$ On May 1 there was a huge demonstration in a Budapest park. It had been organized by independent trade unions and attended by tens of thousands. And finally, of course, on June 16 the reburial of former Prime Minister Imre Nagy and his fellow martyrs from the 1956 revolution drew 250,000 participants and revealed massive popular support for the opponents of the communist regime. ${ }^{10}$

The negotiators could feel the support of ordinary men and women even after the agreement of September 18, 1989, when some parties from the Opposition Roundtable started a petition campaign for a referendum to settle the unresolved questions of the talks by popular decision. In a matter of three weeks, they were able to collect more than 200,000 signatures on the streets. So the negotiated revolution in Hungary went well beyond the scope of small, well-organized elite groups. 
The negotiations were supported by large masses and led to the first post-communist free elections in 1990.

International factors also played a role: most notably the visit of U.S. President George Bush and the support of Soviet party chief Mikhail Gorbachev. ${ }^{11}$ Internal pressures from below as well as external pressure from the Western democratic communities both proved to be important. The by-elections in late July reinforced the notion that the opposition had gained strength. It is true that until March 1990 none of the negotiating parties' positions had been legitimized by democratic elections. Still, the emerging political society clearly supported the self-appointed intellectual groups' struggle for democracy.

\section{The Participants in the National Roundtable Talks}

The participants of the negotiated revolution of 1989 had arrived from many different places and with very different biographies. Then one day they found themselves sitting next to each other and discussing the issues of democratic transition. ${ }^{12}$ Depending on their degree of involvement, they spent weeks or months together debating the future of their country. And after the historic moment had passed, they all went their own way. Some became professional politicians in the different party elites; others went into business; still others returned to their previous careers. For some the experience proved to be a crucial turning point in their lives, while for others it was just a short excursion into the world of politics and left no lasting effects.

Although by now most of the data is available, no exhaustive analysis has been made of the social and political backgrounds of the 573 participants of the roundtable talks. From our former and still unfinished investigations I can summarize some major findings on the comparison of the participants according to their age, gender, profession and places of origin. Those who were born between 1944 and 1953 made up more than one-third of the participants. This generation was strongly influenced by the opening up of the Hungarian regime in 1968 and by the reform period from 1968 to 1972 . They had also been impressed by certain Western cultural and political tendencies of the late sixties. The second largest age group was composed of the youngest participants. One-fourth of the participants was born after 1954; consequently they were age thirty-five or younger in 1989. As a whole those under forty-five composed $64 \%$ of the negotiators. The relative youth of the negotiators is remarkable because until the second half of the 1980s the old regime was led by a gerontocratic oligarchy of first generation communists, who tended to regard even fifty-year-old cadres as youngsters. These data

suggest that those members of the MSZMP who were willing to negotiate and 
therefore participated in the roundtable talks mainly came from the less ideological, more pragmatic, second generation. Although the MSZMP negotiators were still on average a bit older than the other participants, they were already significantly younger than the first communist generation. One of the "secrets" of the smoothness of the transition was that a generational change in the lower and middle level ranks of the MSZMP had preceded the regime change.

The MSZMP negotiators came basically from three different groups. Some came from the headquarters of the Party and represented a relatively more "hardline" position. Others came from different secretariates in and around the Németh cabinet. These included people such as advisors to Imre Pozsgay, Péter Medgyessy and the like, who were strongly in favor of reforms. Finally, a number of MSZMP negotiators came from various ministries and different executive bodies of the state administration. These included lawyers, economic experts and bureaucrats, who often did not consider themselves to be "political animals," and some of whom were not even members of the communist party.

The Opposition Roundtable was a mix of generations covering everybody from the oldest (BZSBT, FKGP, KDNP, MNP, MSZDP) to the youngest (Fidesz). The historical experiences of the oldest and the youngest members of the opposition differed a great deal. While the elderly representatives of the former groups were the most cautious in the negotiations, the young Fidesz representatives, who had not personally experienced the full rigidity of the regime behaved most radically. As far as the Third Side was concerned, there was no over-represented age group among its members.

Of the participants $87 \%$ were men and only $13 \%$ were women. The proportion of women was only $8 \%$ among the representatives of the Opposition Roundtable, while their proportion reached $21 \%$ among the negotiators of the Third Side. Part of the explanation for the relatively high percentage of women in this group is that the representatives of the Alliance of Hungarian Women were included in the Third Side. At the same time the Third Side was the most politically weightless party in the negotiations. It seems that there was a negative correlation between the importance of a political organization and the participation of women in that organization. One can form a hypothesis by saying that first, the more "historic" the organization, the less representation was given to women; and two, the closer a party stood to power, the fewer opportunities were offered to women in its ranks.

The data concerning the educational and professional background of the participants makes clear that almost exclusively intellectuals, or professionals, participated in the negotiations. Their proportion reached 90\% among the participants. Most of them - one-third of all participants - came from "freelance intellectuals," while others came most commonly from the legal-administrative sphere and from the state-owned companies. Among the MSZMP delegates, the proportion of administrative-govemmental professions was $75 \%$. Most of the MSZMP 
delegates preferred to define themselves as "experts" rather than as "party cadres." Independent intellectuals were far over-represented in the organizations of the Opposition Roundtable, where their proportion reached 70\%. (Due to Fidesz, there were more than a dozen university students as well.) The parents of half of the intellectuals had also been intellectuals. Multiple generation intellectuals were characteristic in the ranks of MDF, SZDSZ and the League of Independent Trade Unions (FSZDL). First generation intellectuals dominated the MSZMP, and these were also notable in the ranks of FKGP and Fidesz.

If we look at the twelve Working Committees, we will not be surprised to find that people with degrees in economics dominated the committees concerned with the economy. Following Hungarian traditions that reached back centuries, lawyers took the lead in the debates of the political committees. The lawyers formed the majority in all but one political committee. People with degrees in the arts and the humanities ruled the committee that discussed the reform of the media; and people born in Budapest constituted 50\% of the participants. The rest came in roughly equal proportions from other cities, towns, and villages. But in the actual negotiations, however, the inhabitants of Budapest were far over-represented, due to the simple fact that the talks took place in the Parliament building in the capital, and people living in the countryside could not afford to travel to Budapest two or three times a week.

Only $10 \%$ of the participants did anything before 1989 that could be judged as even moderate oppositionist activity. By oppositionist activity we mean signing a petition, disseminating samizdat journals in friendly circles, or participating in an opposition meeting (in Monor, Szarvas, or Lakitelek), or in movements (such as the independent peace or environmentalist groups). Just as most of the members of Hungarian society, $90 \%$ of the participants had remained silent during the Kádár era. Only one-third of the participants in the negotiations ran for office in the first free elections in March-April 1990, and only one-fifth of them did so during the second elections in $1994 .{ }^{13}$

To sum up, the "regime changing elite" of the negotiators was younger and better educated than the members of the previous elite. Many negotiators held degrees in economics, law, or one of the humanities. These people were overwhelmingly males from Budapest. Many belonged to the "freelance" intellectual circles, while others can be associated with various government bureaucracies. Although this new, or transitory, elite was much better educated and more innovative than the leadership circles of the Kádár regime, in terms of male/female representation it remained just as segregated as the old elite had been. 


\section{Political Values and Visions}

Among the most important political values of 1989, I would like to discuss the following: freedom, non-violence, sovereignty, representative government, consensual democracy, and civil society. The most important vision of the future concerned a democratic society, which "returns to Europe" and enjoys widespread social welfare, a market economy, representative government, and an internationally neutral military.

Among the political values expressed by the participants of the roundtable talks one should above all mention the idea of freedom, which was understood both as a liberal and as a democratic value. Freedom as a liberal value meant the possibility that people finally could exercise their human rights and civil liberties. They could freely talk to each other, both privately and publicly. The press was declared to be free. The rights to associate and form political parties were also considered to be the inevitable rights of all citizens. Freedom was understood negatively rather than positively. This meant that the state (the Party, the police, the military, in short the government) should stay away from individual citizens and should not harass, disturb or control them. This constituted a freedom from something, freedom from the intervention of the state. Such an understanding of freedom clearly resulted from an aggregation of two major political influences. First, the roundtable participants' idea of freedom derived from the legacy of dissent in East Central Europe. This dissent placed a high value on human rights and an equally high value on human dignity (see the writings of Benda, Bibó, Havel, Konrád, Kundera, Kuron, Michnik, Patocka, and others). On the other hand, this concept of freedom also owed a debt to the then dominant Western neo-liberal and neo-conservative ideologies represented by theorists such as Hayek and Friedman, as well as by politicians such as Thatcher and Reagan.

The democratic conception of freedom was understood as a popular sovereignty, recovered after decades of Soviet occupation, during which the presence of the Soviets and the Red Army always strongly influenced the political calculations. Interestingly, democracy was understood as a representative form of governance, where people exercise their constitutional powers not so much directly, but rather through the activities of their elected representatives. If democracy, as Robert Dahl emphasized, consists of three major elements: competition, participation and civil liberties, it is interesting to note that the Hungarians emphasized the first and the third components and did not speak much about the second. Since communism based itself on the forced, involuntary participation of the masses, people were not eager to insist on the value of political mobilization from the top to the bottom. In a way they preferred a liberal, "non-participatory" democracy. 
One of the reasons why the Hungarian regime change was so smooth lies in its cautiously defended peacefulness. Non-violence was highly valued and taken seriously by all sides. I would even say that non-violence was viewed as almost as important as freedom and remains among the central legacies of 1989. The negotiators desired non-violence, accompanied by negotiations, and a tended to strive for a consensus. Ordinary people did not want to repeat the revolution of 1956. But their behavior was also influenced by the evolutionist strategy of the opposition. Nor did the communist holders of power want to initiate violence. Both sides were waiting for each other to respond with violence; but fortunately no one did. The determination for non-violent conflict resolution was accompanied by the then still vital legacy of self-limiting political behavior. Even the so-called radical opposition was, in fact, quite moderate in comparison with other radical democratic oppositions, especially those of Latin America. This value came from the decade-long co-operation of the democratic oppositions of Poland, Hungary, and Czechoslovakia. The high moral value of non-violence, among other political values, was just recently hotly debated and re-evaluated in relation to the NATO air strikes in Yugoslavia. In the spring of 1999 there was a split in Hungarian public opinion on how to evaluate the NATO intervention, which followed the crisis in Kosovo. Members of one camp felt that the intervention went against the legacy of 1989, while people in the other camp felt that, after all, freedom was more important than non-violence. People had to re-think whether non-violence should be evaluated as highly as freedom.

The reason why non-violence was so important lies in the violent legacy of 1956. Everybody wanted to avoid another bloody revolution. Just as in the case of Poland, the legacy of 1980-81 constituted the starting point for the negotiation process all over East Central Europe. In Hungary learning the lessons of nonviolence proved to be a long process. Nevertheless, this peaceful, consensus-building, deliberative process formed democracy through negotiations and in a nonviolent way. The ideal form of democracy was therefore seen as a consensual democracy. The participants in the negotiations agreed that transitory institutions might survive the period of transition. Later they will be re-established as inseparable parts of the new democracy. This consensualism was later harshly criticized by the radical Right, which wanted a more sweeping change in the power relations of the elite. Prime Minister József Antall, the leader of the MDF government, had a famous reply to these claims. He said that the radicals should have made a revolution ("tetszettek volna forradalmat csinálni”), if they wanted a complete change of the elite. This is not to suggest that overarching consensualism is the ideal form of democracy, but this attitude reflected perhaps a more naive approach to democracy, which had been current during the transition. The consensualist views had been influenced by many different thinkers, from Rousseau to Lijphart, and the theorists of civil society. 
Up until 1989 the victory of democracy was imagined as a victory of civil society over the state. A strong state was understood as a sign of a weak democracy and vice versa. One interesting feature of the Opposition Roundtable was that it transformed wishes concerning a united front, an umbrella organization of opposition, into the reality of a newly emerging political elite. This new political elite could be characterized as internally divided and conflict ridden, but also as the co-operative, consensus oriented body of the opposition.

Democracy is about conflicts, conflicting values, and interests. Decisions should be made on the democratic principle of majority rule and the liberal principles of equal human rights and civil liberties. As Hirschman and others have pointed out, conflicts are not dysfunctional in a democracy. Indeed, they are the very essence of it. The point is not to eliminate conflicts in the name of consensualism, but to channel the conflicts through the functioning democratic institutions. Political visions were based on the idea of a "return to Europe" and the new Hungarian politicians took it almost for granted that "the West" would be eager to embrace the newcomers and accept them into the world of democracy. Ten years later we can safely say that this has not proven to be the case. The MDF first advocated the idea of a "third way" but then in order to promote a safer and less painful transition abandoned it and started to emphasize Konrad Adenauer's "social market economy." The liberal parties, on the other hand, influenced by contemporary neo-liberalism, spoke of a "liberal market economy," based on a non-interventionist state. ${ }^{14}$ For a while Finlandization served as a model for Hungary, and the development of Austria was repeatedly mentioned as well. Both cases suggested a militarily neutral status for the country. At that time such neutrality constituted the best that could be hoped for. Only beginning in 1990 did some politicians start to speak of joining NATO. At that time the European Community (later Union) was still far more popular than NATO because it was identified with welfare, and people did not feel any external fear that might induce them to think of joining NATO. This public attitude only started to change after the coup in Moscow in August 1991 and, most visibly, after the war in the former Yugoslavia.

\section{Historical References}

I have already mentioned the legacy of the 1956 revolution as a pattern that most of participants in the regime hoped to avoid. The only exception was the Hungarian October Party, led by György Krassó, which did not participate in the Roundtable Talks and opted for a revolutionary strategy. But this party remained on the margins of political life. The Hungarian October Party criticized the negotiating partners as different elite groups talking over the people's heads and suggested that the parties at the roundtable talks were only interested in following 
their own self interests and not the common good. All other parties insisted on taking a peaceful path from dictatorship to democracy and thus refused to take a revolutionary road. Nevertheless, all of the parties had to deal with the legacy of 1956. They could not possibly ignore it. The revolution crushed by the Soviets and the execution of Imre Nagy, the revolutionary prime minister, made the political position of those who supported János Kádár and associated themselves with his policies morally unacceptable. To remind the public that Kádárism had been born in the state of an "original sin" was the best tool for the opposition to delegitimize the communist regime. The events of 1956 were important as long as they served the opposition's goal of distinguishing itself from the Kádár regime and proved useful for denouncing the Kádár system on moral grounds. While for some speakers at the reburial of Imre Nagy and his fellow martyrs Nagy constituted a role model in politics, for the young radical Viktor Orbán, Nagy was an honorable person only because he had been able to rid himself of his communist beliefs. Nobody from the opposition wanted to follow either Nagy's ideas of a "democratic socialism," or the revolutionary practice of 1956. After June 16, 1989, the moment when communism was morally sentenced to death publicly in Budapest, the legacy of 1956 as the first anti-totalitarian and anti-communist revolution, faded away as well.

Thus the participants of the Roundtable Talks had to search for other usable historical references. As it turned out, Hungarian history had produced some similar patterns of change, which offered some symbolic rediscovery for 1989. First and foremost, during the "lawful revolution of 1848" the lower noble strata had initiated a bloodless transition, a "glorious revolution," 15 which was supposed to have led from a more traditional to a more civic and liberal regime. In 1848 the old parliament had passed the bills necessary for the change that made the famous Batthyány cabinet possible. This government had included ministers such as Kossuth, Széchenyi, and Eötvös. Historians at the roundtable, including György Szabad, József Antall and András Gergely, often referred to the example of 1848 as a model worthy of being followed.

The re-start of political life after World War II constituted yet another reference point. The bill 1946:I on the legal status of the president of the republic was often quoted as the "little constitution" of those times. ${ }^{16}$ It contained legislation on the procedure for electing the president, and by adopting that bill, the opposition wanted to follow the parliamentary traditions of Hungarian politics. They did not favor a presidential system. Politically, 1848 provided the idea of national liberalism that demonstrated the harmony of the values of "homeland" and "progress." On the other hand 1945 supplied a legacy of a peacefully established democratically oriented regime based on a center-right umbrella party, which was at that time the Independent Smallholders' Party. Both legacies were seen as focusing on institutional rearrangement rather than on revolutionary upheaval. The establishment of 
the historic link of 1848-1945-1989 was an important achievement by the Opposition Roundtable. ${ }^{17}$ This connection allowed the Opposition Roundtable to present itself as the heir to the peaceful and radical democratic traditions of Hungarian history.

As far as the foreign historical and political references were concerned, explicit references were made to the Spanish way to democracy in the 1970s. Both government and opposition studied the Spanish transition quite thoroughly. But the most important foreign reference point was obviously Poland. The idea of an "ethical civil society," 18 and the new political evolutionary theories were taken from the experiences of the Polish opposition. Moreover, frequent personal contacts were developed between the members of the Polish and the Hungarian oppositions. Members of the Hungarian democratic opposition had long ago established friendships in Poland with Michnik, Kuron, Smolar and others, while the activists of the new Hungarian trade unions were eager to establish links with Solidarity in order to learn about the Poles' negotiating experiences.

\section{Revisited: On the Costs and Benefits of the Smooth Change}

The roundtable negotiations of 1989 created an unprecedented historical situation in which a political elite was able to craft the constitution and the institutional framework of a democracy. Nevertheless, in many countries, it was not seen as "clean" process. The "original sin" of the negotiations of 1989 was that those talks had included the communists, as the MSZMP leaders also participated in this crafting process. Although the communists were sitting on the other side of the table, they were undeniably there. The uneasiness of the former opposition forces with this situation was accurately represented recently in a statement by the current Hungarian Prime Minister Viktor Orbán. Although Orbán had been an active and even an enthusiastic participant in the 1989 negotiations, he later changed his mind and observed that the costs of the negotiations were actually higher than their benefits. In June 1999 he gave a speech in Vienna, at another conference on the roundtable talks. Orbán said:

\footnotetext{
I ask myself, is there anything that should have remained from 1989. In a vague sense many people think that it was the first year of liberty. Others, and I include myself, believe that 1989 was the last year of dictatorship. Consequently, I think the less that has remained from 1989, the better. ${ }^{19}$
}

Once again this is the question of the bottle that can be seen as half-full, or as half-empty, at the same time. Obviously 1989 was the last year of the dictatorship 
because it was also the year of the collapse of the dictatorship. Orbán's statement served to fulfil some ideological purposes. He wanted to emphasize the need for a sharper discontinuity, and by so doing he distinguished between the 1989-ers and the 1990-ers. And he added that the ' $89 \mathrm{ers}$ are the people of continuity because they were sitting there and negotiating with the communists. On top of that, he basically claimed that the '89ers were only interested in slow changes and partial changes. They were interested in modifying the institutional order but did not want to change the personnel in the media. Moreover, they were not in favor of a fair privatization or a fair economic transformation. On the other hand, as opposed to the ' $89 \mathrm{ers}$, for Orbán, the '90ers are the people of a radical break. They are the people of free elections, and they are not going to enter into the mishmashing of things in the way the '89ers were doing.

Orbán continued by describing some of the costs of 1989: namely that former communists remain in the forefront in the public and commercial media, and that during the privatization process the former communists could transfer public money into their own private hands. This is an interesting argument; for it attempts to portray the roundtable talks as the safest way for communists to preserve themselves for the future. If we study the round table process in the light of this criticism, we may note that the discussions had a formal structure that covered, at least theoretically, both political and economic issues. And the political negotiations proved to be far more important than the talks on the economy. Why was this so? Because the Opposition Roundtable, which favored negotiations, claimed that they were there to legislate new bills. So, for those people, who were at the Opposition Roundtable, the major goal was to achieve popular sovereignty, or pluralistic democracy, and they were against all of those organizations that had allied themselves with organizations having monopolistic powers. So, they were interested in designing the fundamental institutional changes necessary for a new democracy. They were not so much involved in discussions about privatization and the issues of economic transformation. Why was this so? Were they not interested in the economic matters at all? No. They simply did not feel entitled and legitimized by the people to discuss issues of economic policy. Even at the beginning of the talks, the Opposition Roundtable resisted re-writing the constitution. The participants argued that the discussions over economic matters should be carried out in the future by the freely elected parliament and the new government.

In order to achieve economic change one can set up a new institutional order in a matter of months but it is much more difficult to control a privatization processes and design an economic transformation in practice. And, after all, these people on the opposition side of the roundtable talks were uncertain whether they should control privatization at all. Although rhetorically they were always against it, the negotiators finally accepted a spontaneous transformation. They thought that they had started to build a democratic/market society in order to build capital- 
ism. So, if they were in favor of capitalism, they could not oppose spontaneous privatization, which was understood as original capital accumulation, as the "hardware" of capitalism. The participants argued that in terms of history it is not particularly important who is going to be the new owner. The important thing was not so much to put good or reliable guys into positions of ownership but to change fundamentally the economic and political relationships. They thought in this way perhaps because of their ideological foundations, but also because the outgoing technocratic communist elite had already secured the necessary privatization bills before the trilateral talks began in June 1989. The laws on the companies and the economic transformation had been already enacted in 1988 or early 1989 . So, there was not much talk on this issue at the roundtable talks. The economic committees in the roundtable talks found themselves in a vacuum. Members of these committees were sitting together, speaking about privatization and agrarian policies, but they did not conclude with any decisions. Finally, these questions were left to the Blue Ribbon committee and the Bridge committee, which were to be formed by late 1989 .

While political change and institutional change were under the more or less strict oversight of the public, or at least those processes were more visible, the games of economic transformation proceeded largely unnoticed. The legislation of the outgoing government and the installation of expert committees for discussing the strategy of economic transformation were much closer to the elitist design of economic change than was the case in the political negotiations.

Some of the anger expressed by those who only came to power late, or only in the post-privatization phase, may be understandable. Still, I think, it is their misfortune, and I do not think that a "second revolution" needs to be implemented. I think, those radicals who would like to re-start the revolution cannot win elections. Those who are playing with revolutionary rhetoric in order to stimulate another "regime change" can only lose. The change of regimes has been accomplished, and another democratic regime change is not on the agenda of the majority of society. However, these critics wanted to expand the meaning of transition from one of narrow institutional political change to an overarching concept that included broad cultural, economic, and political transformation. Post-1989 radicalism has its democratic limits, and this was recognized recently by Prime Minister Orbán, who has claimed that the change of regimes is finally over.

If we enter a discussion of the cost/benefit analysis of the roundtable discussion, then I believe that the benefits will prove to be far more significant than the costs. The costs are mainly observable in the collective mentality. Many people feel that the economic transformation and the redistribution of economic power did not proceed democratically. People feel that they have somehow been robbed by the "Big Business" that has emerged. The managers, the technocratic elite - all those who were already co-opted by the old Kádárist elite - are viewed as the 
ultimate winners of the transformation. Ordinary people tend to think that they were the victims of communism before the change of regimes, and now they are the victims of globalization.

In terms of the narrower political change, there was a clear elite settlement, a rapid re-negotiation of the political and institutional-legal situation. ${ }^{20}$ In terms of economic change, however, it was a mixture of elite settlement, co-optation, and convergence. These were parallel processes. There were no competing elite groups for the new technocracy. The "new entrepreneurs" of the late Kádár era won the battle. Being still close to the circles of power, the economic elite of the late Kádár era could not be excluded from the benefits of the economic transformation. ${ }^{21}$ Like it or not, they were a part of the game. Their success was part of the price to be paid to avoid revolutionary methods and to accomplish a peaceful transition.

\section{Notes}

1. On the Polish negotiations see: Wiktor Osyatinski, "The Roundtable Talks in Poland," in Jon Elster, ed., Roundtable Talks and the Breakdown of Communism (Chicago: The University of Chicago Press, 1996), 21-68.

2. See Neal Ascherson, The Polish August: The Self-Limiting Revolution (New York: Viking, 1983); Jadwiga Staniszkis, Poland's Self-Limiting Revolution (Princeton: Princeton University Press, I984).

3. For the minutes of the negotiations see: András Bozóki, Márta Elbert, Melinda Kalmár, Béla Révész, Erzsébet Ripp and Zoltán Ripp, eds, A rendszerváltás forgatókönyve: kerekasztaltárgyalások 1989-ben, 4 vols., (Budapest: Magvető, 1999) [from now on: ARF]; on the historical context of the Hungarian negotiations see Rudolf L. Tőkés: Hungary's Negotiated Revolution (Cambridge: Cambridge University Press, 1996).

4. Independently of each other, both the communists and the opposition sent delegates to Poland in May 1989 to learn firsthand the experiences of the Polish negotiators.

5. This was a characteristic argument by Viktor Orbán of Fidesz in 1989, and the other radicals in the opposition bloc accepted it.

6. See for instance: Samuel P. Huntington, The Third Wave: Democratization in the Late Twentieth Century (Norman: University of Oklahoma Press, 1991); Richard Gunther, P. Nikiforos Diamanouros and Hans-Jürgen Puhle, Elites and Democratic Consolidation in Southern Europe (Baltimore: The Johns Hopkins University Press, 1995).

7. Joseph Schumpeter, Capitalism, Socialism and Democracy (New York: Harper \& Bros., 1942).

8. On this see in detail: Alan Renwick, "Eliten kívüli erők szerepe a rendszerváltásban," in András Bozóki, ed., Alkotmányos forradalom, vol. 7, ARF (Budapest: Új Mandátum, 2000) [forthcoming].

9. On this see: Tamás Hofer, "Rendszerváltás szimbolikus mezőben: 1989 március 15-e Budapesten”. Politikatudományi Szemle 1/1 (1992).

10. János Rainer M., “A rendszerváltozás és az ötvenhatos hagyomány,” in András Bozóki, ed., Alkotmányos forradalom, vol. 7, ARF (Budapest: Új Mandátum, 2000) [forthcoming].

11. Interestingly Gorbachev and Bush did not urge the Hungarians to speed up the tempo of the transition. Instead, they warned them that the process of democratization should be kept controlled and the direction of the changes is more important than their speed. It seems that the Hungarian negotiators were more impatient and more eager to speed up the process of change than the 
pro-democratic politicians in either the East or the West. See in detail: Csaba Békés, "Vissza Európába: A magyarországi rendszerváltás nemzetközi háttere,” in András Bozóki, ed., Alkotmányos forradalom, vol. 7, ARF (Budapest: Új Mandátum, 2000) [forthcoming].

12. On the biographies of the main participants see: Márta Elbert and András Bozóki, Portrék és életrajzok, vol. 8, ARF (Budapest: Új Mandátum, 1999); on the analysis of the biographies see András Bozóki and Gergely Karácsony, "Életút és politika: a kerekasztal-tárgyalások résztvevői," in Bozóki, ed., Alkotmányos Forradalom, vol. 7, ARF (Budapest: Új Mandátum, 2000) (forthcoming).

13. Empirical data are based on and taken from the 1996-1997 research on the Hungarian change of regimes, which was led by András Bozóki and co-ordinated by Krisztina Schay at the Department of Political Science of the Central European University, Budapest.

14. On the linguistic battles of the transition see: András Bozóki, "The Rhetoric of Action: The Language of the Regime Change in Hungary," in Intellectuals and Politics in Central Europe, ed. András Bozóki (Budapest-New York: Central European University Press, 1999), 263-283.

15. The notion of a "glorious revolution" stems from the English "transition" of 1688. For the application of this term to 1989 see: Ferenc Fehér and Ágnes Heller, Kelet-Európa dicsőséges forradalmai (Budapest: T-Twins, 1992).

16. The text of the 1946:I bill can be found in ARF, vol. 3 (1999), 645-648.

17. See especially the contributions of József Antall in the August 29 meeting of the Opposition Roundtable; see also: János Kis, "1989: a víg esztendő," Beszélo" 4/10 (1999): 22-46. For the documents see: ARF, vo1. 3 (1999), 520-653.

18. See the chapter on Poland in Juan J. Linz and Alfred Stepan, Problems of Democratic Transition and Consolidation (Baltimore: The Johns Hopkins University Press, 1996).

19. See Viktor Orbán's speech at a conference entitled "Ten Years After" and held at Vienna, Austria on June 26, 1999. www.meh.hu/kormany/kormanyfo/1999/O6/990626 becsen.htm

20. Michael G. Burton and John Higley, "Elite Settlements," American Sociological Review 52(1987): 295-307; John Higley and Michael G. Burton, "The Elite Variable in Democratic Transitions and Breakdowns," American Sociological Review 54(1989): 17-32; John Higley, Jan Pakulski and Wlodzimierz Wesolowski, eds, Postcommunist Elites and Democracy in Eastern Europe (London: Macmillan, 1998).

21. On this see for example: Erzsébet Szalai: Gazdaság és hatalom (Budapest: Aula, 1990).

\section{Further information:}

András Bozóki is the editor-in-chief of a project to publish all of the documents of the Hungarian roundtable talks of 1989. The first four volumes of the eight volume series were published as $A$ rendszerváltás forgatókönyve: Kerekasztal-tárgyalások 1989-ben [The Script of the Regime Change: Roundtable Talks in 1989] (Budapest: Magvető, 1999); the 5th and 8th volumes were published by Új Mandátum in 1999 and 2000 respectively; the 6th and 7th volumes are to be published by Új Mandátum in May 2000. These books are and will be available in Hungarian. A CD version of the eight volumes is also under preparation. One volume will be published in English: the minutes of the National Roundtable talks, which will (I hope) be published by the Central European University Press.

Previous books on this topic include:

András Bozóki, András Korosenyi and George Schopflin, eds, Post-Communist Transition: Emerging Pluralism in Hungary (London: Pinter, New York: St. Martin's Press, 1992).

Béla K. Király and András Bozóki, eds, Lawful Revolution in Hungary, 1989-94 (Boulder: Social Science Monographs, 1995).

András Bozóki, ed., Intellectuals and Politics in Central Europe (Budapest-New York: CEU Press, 1999). 


\title{
Appendix 1
}

\section{THE STRUCTURE OF THE NATIONAL ROUNDTABLE TALKS IN HUNGARY, 1989}

\author{
Plenary Session \\ (Agreements, political declarations) \\ (3 delegates from each participating organizations)
}

\section{Middle-level Sessions}

Political coordinating committee

(Defining the rules and principles of the democratic transition.)

(2 delegates from each organizations)
Economic and social committee (Strategic issues in combating economic and social crisis.) ( 2 delegates from each organizations)

\section{Working Committees}

1. Political committees

(5-5 delegates from the three sides)

1.1 Constitution drafting (President, constitutional court)

1.2 Legal regulation of political parties (Party finance, party assets)

1.3 Electoral law

1.4 Remaking of the penal code and the Rules of criminal procedural law

1.5 Liberation and regulation of the mass media. (Public TV, newspapers)

1.6 Legal guarantees for the completion of the non-violent transition to democracy
2. Economic committees (5-5 delegates from the three sides)

2.1 Debt problem, structural change, inflation

2.2 The social consequences of the economic crisis

2.3 Property reform, privatization

2.4 Land reform. (The problem of agricultural co-operatives.)

2.5 Principles of the budget regulation

2.6 Anti-monopoly regulations, protection.

\section{Goodwill Committee}

(To solve problems in the negotiating process, operating every level.) 
Appendix 2

\section{PARTICIPANTS AND THEIR POSITION AT THE NATIONAL ROUNDTABLE TALKS \\ (in fact trilateral talks)}

1. MSZMP - Hungarian Socialist Worker's Party (Communist Party)

Internally divided, but increasingly dominated by reformist elements, willing to negotiate and compromise.

2. Opposition roundtable (9 organizations)

"Ultra-moderates"

Bajcsy-Zsilinszky Society (BZSBT)

Christian Democratic Party

Hungarian People's Party (MNP)

(Center-right, cultural-political association)

("Historic" party, center-right, Christian/social)

("Historic" party, center-left, third way)

"Moderates"

Hungarian Democratic Forum (MDF)

Independent Smallholders Party (FKGP)

League of Free Trade Unions (FSZDL)

Social Democrats (MSZDP)

(New; centrist, national/liberal/conservative, mixed)

("Historic" party, agrarian/traditionalist)

(New; union led by urban intellectuals)

("Historic" party, internally divided)

"Self-limiting Radicals"

Alliance of Free Democrats (SZDSZ)

Federation of Young Democrats (Fidesz)

(New; social/economic liberal, former dissidents)

(New; liberal/radical/alternative, students etc.)

\section{Third side (7 organizations)}

National Council of Trade Unions (SZOT)

Patriotic People's Front (HNF)

(official unions, puppet organization of the $\mathrm{CP}$ )

Democratic Youth Alliance (Demisz)

Women's Alliance (MNSZ)

Ferenc Münnich Society (MFT)

Alliance of Resistance Fighters and

Anti-fascists (MEASZ)

Left Alternative

(reform-minded; umbrella organization)

(formerly: Communist Youth League)

(puppet organization of the $\mathrm{CP}$ )

(hard-liner, Cold War-communists)

(WWII communists, former partisans)

(intellectuals in the humanities) 